\title{
Penggunaan Perangkat Lunak Energy2D dalam Mempelajari Konduktivitas Panas Pada Plastik
}

\author{
B. Budiana*, Rifaldi Dwi Priana*, Xena Mutiara Sinurat", Canderif Amsal Oloan Silaban* \\ *Politeknik Negeri Batam \\ Jurusan Teknik Elektro \\ Jalan Ahmad Yani, Teluk Tering, Kecamatan Batam Kota, Kota Batam, Batam 29461, Indonesia \\ E-mail: budiana@polibatam.ac.id
}

\begin{abstract}
Abstrak
Plastik merupakan salah satu jenis material yang memiliki karakteristik tertentu terhadap panas. Salah satu karakteristik dari plastik yang dapat dipelajari adalah konduktivitas panas. Konduktivitas panas merupakan kemampuan suatu material untuk menghantarkan panas dalam kurun waktu tertentu dan pada ketebalan tertentu. Konduktivitas panas pada plastik dapat dipelajari dengan menggunakan Energy2D. Jenis plastik yang digunakan pada penelitian ini terdiri dari polipropilena, polistirena, HDPE, LDPE dan PVC sedangkan Ketebalan yang digunakan bervariasi mulai dari $1 \mathrm{~cm}$ sampai dengan $9 \mathrm{~cm}$. Berdasarkan hasil simulasi yang telah dilakukan, jenis plastik polipropilena memiliki kurva paling rendah jika dibandingkan dengan semua bahan yang digunakan. Waktu yang dibutuhkan suhu bagian luar (sumber) untuk sama dengan suhu bagian dalam ruangan setelah melewati polipropilena adalah ( $>40 \mathrm{jam}$ ). Selain dari itu, waktu yang dibutuhkan suhu bagian luar untuk sama dengan suhu bagian dalam ruangan akan semakin lama jika polipropilena yang digunakan semakin tebal. Hal ini terlihat untuk ketebalan polipropilena dengan ketebalan $9 \mathrm{~cm}$ yang membutuhkan waktu ( $>60 \mathrm{jam})$.
\end{abstract}

Kata kunci: Energy2D, koduktivitas panas, plastik

\begin{abstract}
Plastic is one type of material that has certain characteristics against heat. One of the characteristics of plastics that can be studied is thermal conductivity. Thermal conductivity is the ability of a material to conduct heat within a certain period of time and at a certain thickness. The thermal conductivity of plastics can be studied using Energy2D. The types of plastics used in this study consisted of polypropylene, polystyrene, HDPE, LDPE and PET while the thickness used varied from $1 \mathrm{~cm}$ to $9 \mathrm{~cm}$. Based on the simulation, the type of polypropylene plastic has the lowest curve when compared to all the materials used. The time it takes for the outside (source) temperature to equal the room temperature after passing through the polypropylene is ( $>40$ hours). Apart from that, the time it takes for the outside temperature to be equal to the indoor temperature will be longer if the polypropylene used is getting thicker. This can be seen for the thickness of polypropylene with a thickness of $9 \mathrm{~cm}$ which takes time (>60 hours).
\end{abstract}

Keywords: Energy2D, heat conductivity, plastic

\section{PENDAHULUAN}

Polimer merupakan salah satu jenis material selain keramik dan logam [1]. Berdasarkan sumbernya, polimer dapat dibedakan menjadi dua macam yaitu polimer alami dan polimer sintetik [2]. Polimer alami merupakan jenis polimer yang berasal langsung dari alam sedangkan polimer sintetik merupakan polimer yang berasal dari sintesis monomer-monomernya.

Salah satu jenis polimer sintetik adalah plastik. Plastik banyak digunakan oleh manusia baik untuk industri makanan, industri elektronik maupun industri otomotif. Penggunaan plastik di Asia mencapai $20 \mathrm{~kg}$ per tahun per orang atau mencapai $30 \%$ dari total 
penduduk dunia. Penggunaan plastik yang tinggi memiliki potensi sampah yang dihasilkannya juga tinggi. Indonesia berada pada urutan ke 2 sebagai negara penyumbang sampah plastik terbanyak di dunia. Jumlah sampah plastik di Indonesia mencapai kurang lebih 85.000 per tahun. Jumlah sampah yang sangat tinggi ini akan berpotensi terhadap tingginya pencemaran lingkungan yang terjadi [3].

Pemanfaatan sampah plastik telah dikaji oleh beberapa peneliti, diantaranya adalah pemanfaatan limbah plastik menjadi biofuel [4], pemanfaatan limbah plastik sebagai bahan kerajinan [5], pemanfaatan limbah plastik untuk aspal [6] dan pemanfaatan limbah plastik sebagai bahan bangunan [7]. Namun, pemanfaatan plastik yang telah dilakukan belum dapat dimanfaatkan secara menyeluruh untuk semua jenis plastik, begitupun teknologi yang digunakan untuk mengolah sampah plastik.

Salah satu kajian yang dapat dilakukan secara intensif adalah pemanfaatan sampah plastik sebagai bahan bangunan. Pemanfaatan sampah plastik untuk bahan bangunan ini sangat menarik untuk dipelajari karena konstruksi bangunan di dunia akan terus berlanjut dan terus mengalami perkembangan seiring dengan kebutuhan manusia terhadap tempat tinggal. Jenis plastik yang biasa digunakan untuk berbagai kepentingan sehari hari terdiri dari high density polyethylene (HDPE), low density polyethylene (LDPE), polypropylene (PP), polystyrene (PS) dan polyvinyl chloride (PVC) [8].

Berdasarkan hal tersebut, penulis melakukan kajian terkait dengan potensi plastik yang dapat digunakan sebagai salah satu material bangunan. Aspek yang dipertimbangkan dalam kajian ini adalah sifat konduktivitas pada plastik. Semakin rendah konduktivitas panasnya maka semakin baik digunakan karena suhu yang berada diluar akan tertahan oleh plastik sehingga suhu ruangan tidak cepat panas seperti suhu yang berada diluar ruangan.

Konduktivitas panas merupakan kemampuan suatu material dalam menghantarakan panas [8]. Persamaan umum yang berkaitan dengan konduktivitas panas dapat dituliskan pada persamaan 1 sebagai berikut:
$\frac{\Delta Q}{\Delta t}=-\mathrm{KA} \frac{\Delta \mathrm{T}}{\Delta \mathrm{X}}$

Dimana:

$\Delta Q$ merupakan fluks panas/jumlah energi panas yang diberikan dari satu titik ke titik yang lain $\left(\mathrm{W} / \mathrm{m}^{2}\right)$ dalam kurun waktu tertentu $(\Delta t)$, K merupakan konduktivitas panas (W/m.k), A merupakan daerah yang dilalui panas $\left(\mathrm{m}^{2}\right), \Delta \mathrm{T}$ merupakan perbedaan panas diantara kedua sisi $\left({ }^{0} \mathrm{~K} /{ }^{0} \mathrm{C}\right)$ dan $\Delta x$ merupakan ketebalan (m) [9].

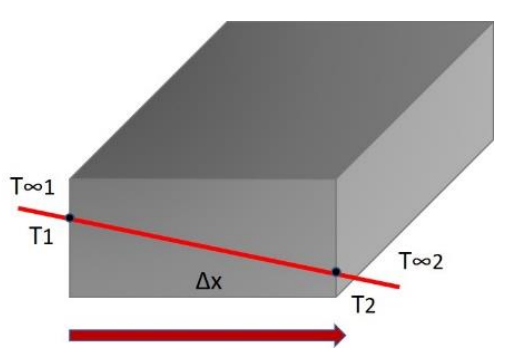

Gambar 1. Perpindahan panas pada material

Kajian konduktivitas panas pada plastik telah dilakukan oleh beberapa peneliti, diantaranya kajian mengenai konduktivitas panas pada polimer dan komposit polimer [10], kajian konduktivitas panas pada beton akibat penggunaan sampah plastik [8], serta konduktivitas panas dan konduktivitas listrik pada polimer yang diisi dengan bahan logam [11].

Selain dari kajian yang telah dilakukan, terdapat potensi lain yang dapat diteliti yaitu kajian mengenai konduktivitas panas menggunakan perangkat lunak. Penggunaan perangkat lunak bersifat menarik karena dapat melakukan prediksi atas konduktivitas yang terjadi pada plastik jika digunakan sebagai bahan bangunan. Konduktivitas panas dapat dipelajari dengan menghubungkan panas yang diberikan terhadap perubahan waktu. Salah satu perangkat lunak yang dapat digunakan adalah Energy2D (Interactive heat transfer simulations for everyone). Energy2D dapat digunakan untuk mempelajari perpindahan panas pada material [12][13][14].

\section{METODE PENELITIAN}

Metode penelitian yang digunakan pada penelitian ini dapat dilihat pada gambar 2 . 


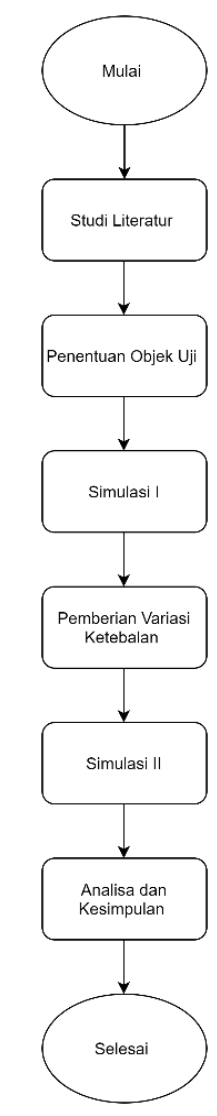

Gambar 2. Diagram alir metode penelitian

\section{A. Studi Literatur}

Tahapan awal dalam penelitian ini adalah studi literatur dari berbagai kajian yang berhubungan dengan konduktivitas panas, sampah plastik, teori tentang plastik dan pengolahannya. Kajian yang dilakukan dengan mengumpulkan infromasi dari berbagai artikel, buku dan informasi yang relevan guna menunjang penelitian yang sedang dilakukan.

\section{B. Penentuan Objek Uji}

Penentuan objek uji dilakukan dalam memilih jenis plastik tertentu yang akan digunakan. Jenis plastik yang digunakan pada penelitian ini terdiri dari high density polyethylene (HDPE), low density polyethylene (LDPE), polypropylene (PP), polystyrene (PS) dan polyvinyl chloride (PVC).

\section{Simulasi I dengan Energy2D}

Objek uji yang telah ditentukan kemudian disimulasikan dengan Energy2D untuk mendapatkan konduktivitas panasnya. Setelah diperoleh hasil simulasi, kemudian ditentukan jenis plastik yang memiliki konduktivitas panas paling rendah berdasarkan kurva yang terbentuk antara lamanya waktu untuk mencapai suhu tertentu.

\section{Pemberian variasi ketebalan}

Variasi ketebalan yang diberikan mulai 1-9 cm. Adapun matriks pemberian variasi ketebalan merujuk pada tabel 1 .

Tabel 1. Jenis sampel yang digunakan untuk simulasi

menggunakan Energy 2 D
\begin{tabular}{|c|c|c|}
\hline \multirow{2}{*}{ Sampel } & \multicolumn{2}{|c|}{ Ketebalan $(\mathrm{cm})$} \\
\cline { 2 - 3 } & Beton & Plastik \\
\hline A & 1 & 9 \\
\hline B & 2 & 8 \\
\hline C & 3 & 7 \\
\hline D & 4 & 6 \\
\hline E & 5 & 5 \\
\hline F & 6 & 4 \\
\hline G & 7 & 3 \\
\hline H & 8 & 2 \\
\hline I & 9 & 1 \\
\hline
\end{tabular}

\section{E. Simulasi II dengan Energy2D}

Pemberian variasi ketebalan sesuai dengan sub bab D disimulasikan kembali dengan menggunakan Energy2D. Hasil simulasi yang dilakukan dapat memberikan gambaran terkait dengan pengaruh ketebalan yang diberikan terhadap material yang diuji.

\section{F. Analisa Data dan Penarikan kesimpulan}

Analisa data dilakukan terhadap kesesuaian teori perpindahan panas dengan hasil yang diperoleh dengan menggunakan Energy2D. Setelah dianalisa, maka akan diperoleh kesimpulan yang berkaitan dengan penggunaan aplikasi Energy2D dalam mempelajari konduktivitas panas pada plastik, pengaruh jenis plastik yang digunakan serta pengaruh ketebalan plastik terhadap lamanya waktu yang dibutuhkan untuk mencapai suhu yang sama dengan suhu sumber pada bagian dalam ruangan.

\section{HASIL DAN PEMBAHASAN}

\section{A. Simulasi pengaruh jenis plastik}

Parameter yang dibuat pada Energy2D terdiri dari 
pemberian suhu masukan, beton, jenis plastik serta suhu bagian dalam ruangan. Adapun simulasi dengan menggunakan Energy2D ditunjukan pada gambar 3.

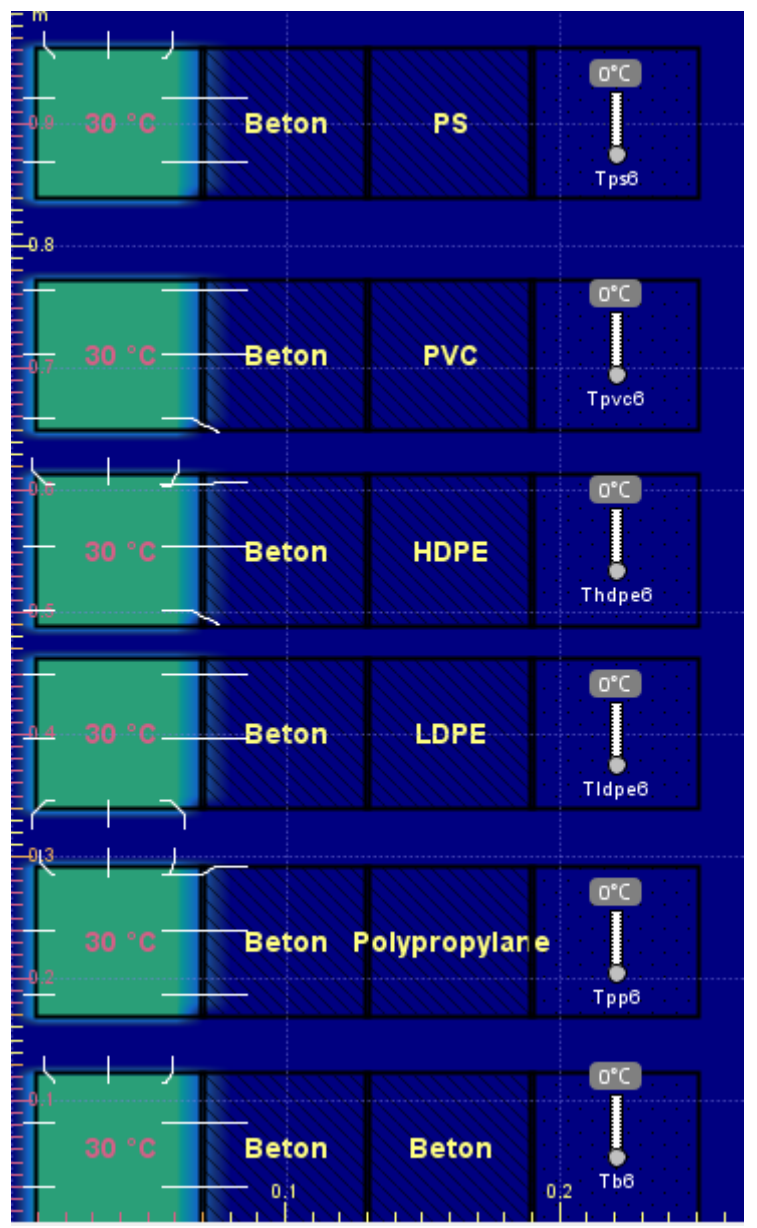

Gambar 3. Pemodelan simulasi untuk berbagai jenis plastik dengan menggunakan Energy2D

Simulasi dilakukan dengan pemberian nilai masukan sebesar $30{ }^{\circ} \mathrm{C}$ (suhu sumber/suhu luar). Pemberian nilai masukan yang diberikan merupakan suhu luar yang akan mengenai beton bangunan. Suhu masukan tersebut akan diteruskan ke beton kemudian ke plastik dan terakhir adalah ruangan bagian dalam bangunan.

Setelah dilakukan pemodelan seperti pada gambar 3, dilanjutkan dengan pembuatan grafik hubungan antara variasi material dengan parameter suhu dan waktu. Waktu yang diambil adalah waktu maksimal yang terjadi dimana suhu masukan sama dengan suhu ruangan bagian dalam bangunan. Adapun hasilnya ditunjukan pada gambar 4 .

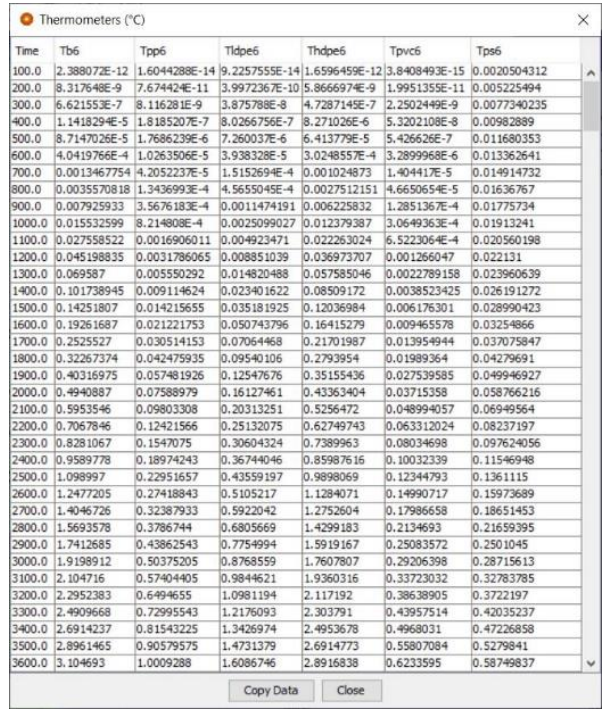

Gambar 4. Data simulasi suhu ruangan bagian dalam setelah melalui jenis plastik dan beton

Dari gambar 4 tersebut, dibuat grafik hubungan antara lamanya waktu terhadap suhu bagian dalam ruangan. Hasil yang diperoleh ditunjukan pada gambar 5 .

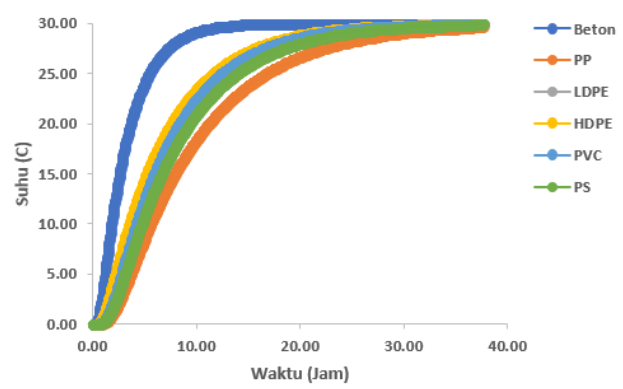

Gambar 5. Hubungan antara waktu (jam) dan suhu (c) untuk semua jenis plastik

Berdasarkan Gambar 5 terlihat bahwa beton tanpa plastik memiliki waktu yang relative cepat untuk mencapai suhu yang sama dengan suhu sumber. Suhu ruangan bagian dalam yang terhalang oleh beton sendiri mencapai nilai $30^{\circ} \mathrm{C}$ (sama dengan sumber) dalam kurun waktu \pm 10 jam sedangkan untuk semua jenis plastik membutuhkan waktu $>10$ jam. Selain dari itu, gambar 5 menunjukan karakteristik dari plastik dan beton sendiri. Untuk semua jenis plastik memiliki karakteristik yang mirip (tumpang tindih) pada titik yang sama sehingga membentuk pola kelengkungan yang identik berbeda dengan pola kelengkungan beton yang memiliki pola tersendiri 
(terpisah dari semua jenis plastik). Namun, pola kelengkungan beton setelah $>20$ jam mendekati pola kelengkungan plastik. Hal ini terjadi karena suhu bagian dalam telah mencapai suhu maksimal $30{ }^{\circ} \mathrm{C}$ (sama dengan suhu sumber yang diberikan) setelah melewati beton ataupun plastik.

Polipropilena memiliki kurva yang paling rendah jika dibandingkan dengan semua jenis material yang digunakan (Gambar 5). Ini menunjukan bahwa polipropilena mampu menahan panas dari luar dengan kurun waktu yang relative lama. Jika merujuk pada hasil tersebut, polipropilena memiliki potensi untuk digunakan sebagai material bahan bangunan karena mampu menahan panas dalam kurun waktu tertentu.

\section{B. Simulasi Pengaruh Ketebalan Plastik}

Berdasarkan simulasi yang dilakukan pada simulasi 1, polipropilena merupakan jenis plastik yang memiliki konduktivitas panas rendah atau resistivitas panas tinggi jika dibandingkan semua jenis material yang digunakan. Sehingga pada simulasi yang kedua, pengaruh ketebalan plastik polipropilena yang akan dikaji dengan menggunakan Energy2D. Ketebalan plastik yang digunakan pada penelitian ini bervariasi dari ketebalan plastik $1 \mathrm{~cm}$ sampai dengan ketebalan plastik $9 \mathrm{~cm}$. Begitu juga dengan ketebalan beton mengikuti variasi pemberian ketebalan pada plastik. Total ketebalan yang digunakan pada penelitian ini adalah $10 \mathrm{~cm}$. Matriks ketebalan beton dan plastik merujuk pada tabel 1 .

Variasi ketebalan beton dan plastik yang digunakan (sesuai dengan tabel 1) disimulasikan kembali dengan menggunakan Energy2D dengan hasil sebagai berikut:

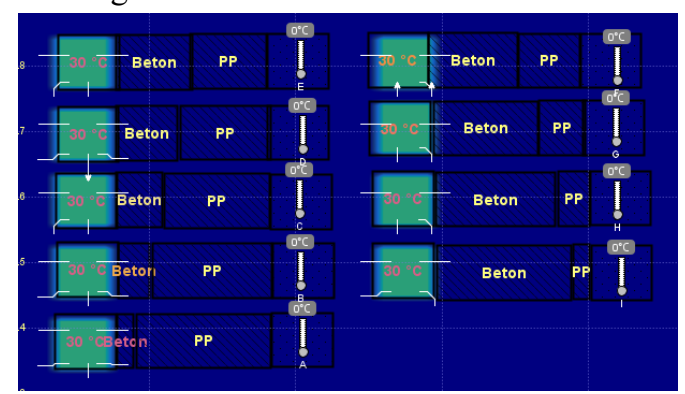

Gambar 6. Simulasi pengaruh variasi ketebalan jenis plastik polipropilena terhadap suhu bagian dalam ruangan
Hasil simulasi pada gambar 6 kemudian dioleh datanya sehingga mendapatkan kurva seperti pada gambar 7 .

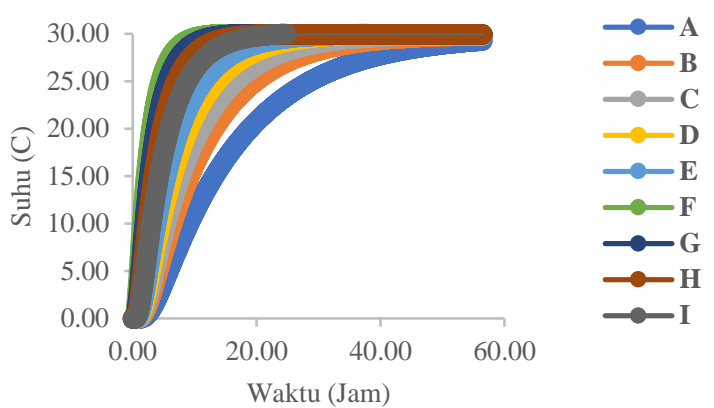

Gambar 7. Hasil simulasi untuk variasi ketebalan beton dan Polipropilena

Kurva yang terbentuk pada gambar 7 menunjukan penyebaran panas dari bagian luar, sampai dengan ruangan bagian dalam. Berdasarkan gambar 7 terlihat bahwa kurva sampel A lebih rendah dari semua kurva yang terbentuk. Hal ini menunjukan bahwa sampel A mampu menghambat panas yang diberikan dari luar (lebih resistif) sehingga suhu bagian dalam ruangan cenderung lebih rendah dari suhu luar/sumber. Lamanya waktu yang dibutuhkan untuk suhu luar sama dengan suhu bagian dalam ruangan pada sampel A, diperkirakan $>60$ jam, sehingga sampel A memiliki potensi yang sangat besar jika digunakan sebagai material beton.

\section{KESIMPULAN}

Pengaruh jenis plastik dan ketebalan plastik telah berhasil dikaji dengan menggunakan aplikasi Energy2D. Semua jenis plastik dan beton menunjukan karakteristik dalam menghantarkan panas. Selain dari itu, ketebalan plastik sangat menentukan proses penghantaran panas dari sumber panas ke bagian dalam ruangan. Berdasarkan kurva yang terbentuk dari hasil simulasi dengan menggunakan Energy2D, polipropilena memiliki potensi untuk digunakan sebagai salah satu bahan bangunan karena memiliki kemampuan menahan panas dari luar yang relative lama jika dibandingkan dengan jenis plastik lain. 
Semakin tebal polipropilena yang digunakan maka semakin besar potensi untuk menahan panas dari luar (memiliki konduktivitas panas yang buruk).

\section{UCAPAN TERIMA KASIH}

Penulis mengucapkan terima kasih kepada Jurusan Teknik Elektro, Polibatam yang telah mendukung pelaksanaan penelitian yang dilakukan.

\section{DAFTAR PUSTAKA}

[1] S. Yadav dan S. Gangwar, "An Overview on Recent progresses and future perspective of biomaterials," 2011, doi: 10.1088/1757899X/404/1/012013.

[2] M. Sohail et al., "Natural and synthetic polymerbased smart biomaterials for management of ulcerative colitis: a review of recent developments and future prospects," Drug Delivery and Translational Research, vol. 9, no. 2. Springer Verlag, hal. 595-614, Apr 15, 2019, doi: 10.1007/s13346-018-0512-X.

[3] Y. A. Hidayat, S. Kiranamahsa, dan M. A. Zamal, "A study of plastic waste management effectiveness in Indonesia industries," AIMS Energy, vol. 7, no. 3, hal. 350-370, 2019, doi: 10.3934/ENERGY.2019.3.350.

[4] M. B. Al Rayaan, "Recent advancements of thermochemical conversion of plastic waste to biofuel-A review," Clean. Eng. Technol., vol. 2, hal. 100062, Jun 2021, doi: 10.1016/j.clet.2021.100062.

[5] S. R. Nasution, D. Rahmalina, B. Sulaksono, dan C. O. Doaly, "IbM: PEMANFAATAN LIMBAH PLASTIK SEBAGAI KERAJINAN TANGAN DI KELURAHAN SRENGSENG SAWAH JAGAKARSA JAKARTA SELATAN,” J. Ilm. Tek. Ind., vol. 6, no. 2, Jun 2019, doi: 10.24912/jitiuntar.v6i2.4119.

[6] H. Naghawi et al., "Plastic Waste Utilization as Asphalt Binder Modifier in Asphalt Concrete Pavement," undefined, 2018.

[7] S. Das dan S. Das, "Properties for Polymer, Metal and Ceramic Based Composite Materials," in
Reference Module in Materials Science and Materials Engineering, Elsevier, 2021.

[8] A. Poonyakan, M. Rachakornkij, M. Wecharatana, dan W. Smittakorn, "Potential use of plastic wastes for low thermal conductivity concrete," Materials (Basel)., vol. 11, no. 10, Okt 2018, doi: 10.3390/ma11101938.

[9] S. S. Alrwashdeh, "Modelling of operating conditions of conduction heat transfer mode using energy 2D simulation," Int. J. Online Eng., vol. 14, no. 9, hal. 200-207, 2018, doi: 10.3991/ijoe.v14i09.9116.

[10] C. Huang, X. Qian, dan R. Yang, "Thermal conductivity of polymers and polymer nanocomposites," Materials Science and Engineering R: Reports, vol. 132. Elsevier Ltd, hal. 1-22, Okt 01, 2018, doi: 10.1016/j.mser.2018.06.002.

[11] Y. P. Mamunya, V. V. Davydenko, P. Pissis, dan E. V. Lebedev, "Electrical and thermal conductivity of polymers filled with metal powders," Eur. Polym. J., vol. 38, no. 9, hal. 18871897, Sep 2002, doi: 10.1016/S00143057(02)00064-2.

[12] C. Xie, "Interactive Heat Transfer Simulations for Everyone," Phys. Teach., vol. 50, no. 4, hal. 237-240, Apr 2012, doi: 10.1119/1.3694080.

[13] F. Landriscina, "An Introduction to Simulation for Learning," in Simulation and Learning, Springer New York, 2013, hal. 1-12.

[14] J. Tu, G. H. Yeoh, dan C. Liu, Computational Fluid Dynamics. Elsevier Ltd, 2013. 